\title{
Nuclear shift of hnRNP K protein in neoplasms and other states of enhanced cell proliferation
}

\author{
J Ostrowski, ${ }^{*}, \mathbf{2}$ and K Bomsztyk ${ }^{3}$ \\ 'Department of Gastroenterology, Medical Center for Postgraduate Education, Maria Sklodowska-Curie Memorial Cancer Center, ul. Roentgena 5, 02- \\ 781 Warsaw, Poland; ' Institute of Oncology, 02-78I Warsaw, Poland; ${ }^{3}$ Department of Medicine, University of Washington, Seattle, WA 98195, USA
}

\begin{abstract}
The heterogeneous nuclear ribonucleoprotein K ( $h n R N P \mathrm{~K}$ ), is a ubiquitously expressed protein that interacts with signal transducers, proteins that modulate gene expression and selective RNA and DNA motifs. K protein is modified in response to extracellular signals and directly regulates rates of transcription and translation. We used serum-treated hepatocyte culture, liver after partial hepatectomy and hepatic neoplasms as systems to compare expression, subcellular distribution and tyrosine phosphorylation of $\mathrm{K}$ protein in quiescent and dividing cells. The results show that expression of $\mathrm{K}$ protein mRNA was increased in states of enhanced proliferation. Levels of nuclear K protein were also higher in proliferating compared to resting cells. In contrast, levels of cytoplasmic K protein were the same or lower in dividing compared to quiescent cells. States of enhanced proliferation were also associated with increased levels of $\mathrm{K}$ protein tyrosine phosphorylation. Nuclear shift of $\mathrm{K}$ protein in dividing cells may reflect involvement of $\mathrm{K}$ protein in signalling multiple events that regulate expression of genes in proliferating cells.

British Journal of Cancer (2003) 89, I493- I50I. doi: I0.1038/sj.bjc.660 I 250 www.bjcancer.com

(c) 2003 Cancer Research UK
\end{abstract}

Keywords: hnRNP K protein; proliferation; hepatocyte culture; hepatectomy; hepatic neoplasms

The heterogeneous nuclear ribonucleoprotein $\mathrm{K}$ (hnRNP $\mathrm{K}$ ) protein is an abundant and ubiquitous factor that interacts with a diverse types of molecules (Bomsztyk et al, 1997) including RNA (Dejgaard et al, 1994), DNA (Ostrowski et al, 1994), factors involved in chromatin remodelling (Denisenko and Bomsztyk, 1997; Shnyreva et al, 2000), transcription (Du et al, 1993), RNA splicing (Shnyreva et al, 2000) and translation (Bomsztyk et al, 1997). K protein also interacts with factors involved in signal transduction, including inducible kinases (Weng et al, 1994; Bustelo et al, 1995; Van Seuningen et al, 1995). The diversity of its interactions can be accounted for by K protein's modular structure (Bomsztyk et al, 1997). $\mathrm{K}$ protein is modified in response to changes in extracellular environment including cytokines, growth factors and oxidative stress (Ostrowski et al, 1991; 2000a). Changes in $\mathrm{K}$ protein phosphorylation regulate its interaction with nucleic acids and protein partners (Schullery et al, 1999; Ostrowski et al, 2000a; Ostareck-Lederer et al, 2002). These properties suggest that $\mathrm{K}$ protein bridges signal transduction pathways to nucleic aciddirected processes. In further support of this model, several studies have shown that $\mathrm{K}$ protein can alter rates of transcription (Michelotti et al, 1996) and translation (Ostareck et al, 1997).

$\mathrm{K}$ protein contains three $\mathrm{K}$ homology $(\mathrm{KH})$ domains (Siomi et al, 1993) that are highly conserved in organisms as diverse as yeast and mammals. In Drosophila, the $\mathrm{KH}$ domain-containing product, bancal, is most closely related to the mammalian $\mathrm{K}$ protein. Null and weak alleles of bancal impair adult appendages morphogenesis (Charroux et al, 1999; Gates and Thummel, 2000). This phenotype reflects decreased cell proliferation in the imaginal disc cells

*Correspondence: J Ostrowski; E.mail: jostrow@warman.com.pl

Received 19 May 2003; accepted 8 June 2003
(Charroux et al, 1999). Expression of human $\mathrm{K}$ protein rescues these fly phenotypes, suggesting that like the structure, $\mathrm{K}$ protein function has also been evolutionarily conserved.

Since bancal has been shown to affect cell proliferation in Drosophila (Charroux et al, 1999; Gates and Thummel, 2000), we wondered if $\mathrm{K}$ protein expression is altered in proliferating mammalian cells. To explore the role of $\mathrm{K}$ protein in mitogenic responses, we chose hepatic cell lineage because cell cultures and useful models of enhanced proliferative states in intact organs and cancer are available. Our study showed increased expression of $\mathrm{K}$ protein mRNA and a nuclear shift of $\mathrm{K}$ protein in cultured serumtreated hepatocytes, in regenerating livers postpartial hepatectomy and in hepatic neoplasms.

\section{MATERIAL AND METHODS}

\section{Cells}

Rat hepatoma cells expressing human insulin receptors, HTC-IR, were grown in plastic cell culture flasks in DME media supplemented with $10 \%$ FBS, $2 \mathrm{~mm}$ glutamine, penicillin $\left(100 \mathrm{U} \mathrm{ml}^{-1}\right)$, streptomycin (0.01\%), and humidified with $7 / 93 \%$ $\mathrm{CO}_{2}$ /air gas mixture.

\section{Animals}

Mice were housed under constant room temperature with a $12: 12$ $\mathrm{h}$ light-dark and permitted free access to water and to standard food pellets. The animals received humane care in compliance with the regulation of Cancer Center. 
Experiments utilised CBA-T6/W mice, which had developed spontaneous hepatocellular neoplasms, and BALB/c mice with liver implanted L1 sarcoma tumors (Ostrowski et al, 2000c). L1 sarcoma cell line was propagated under standard conditions in MEM supplemented with $10 \%$ FCS and antibiotics. BALB/c mice, 2 months old, were anaesthetised with ether for laparotomy, and $10^{5}$ viable $\mathrm{L} 1$ cells suspended in $0.05 \mathrm{ml}$ of PBS were injected under the capsule of left lateral lobe of the liver. After 3 weeks, animals with implanted hepatic tumours were used in these studies. Mice anaesthetised by ether were killed, the livers were rapidly resected and classified by gross examination into tumour and hepatic tissue. Two portions of each specimen were frozen in liquid nitrogen and stored in $-80^{\circ} \mathrm{C}$ until use. The remaining portions were fixed in formalin and embedded in paraffin for histological examination.

Partial hepatectomy was performed under ether anaesthesia on 2-month-old BALB/c male mice. Under aseptic conditions animals were subjected to mid-ventral laparatomy and resection of the left lateral lobe which constitutes about one-third of the total liver. The removed lobe was immediately frozen in liquid nitrogen and stored at $-80^{\circ} \mathrm{C}$ until use. After the indicated times, animals were killed and the remnant liver was rapidly collected and frozen. Sham-operated animals underwent mid-ventral laparatomy without resection of liver lobe.

\section{Northern blot analysis and RT-PCR}

Total RNA was prepared from tissues and cell pellets using TRIzol reagent. A measure of $10 \mu \mathrm{g}$ of total RNA was denatured with formaldehyde-formamide and electrophoresed in a $1 \%$ agarose/ formaldehyde gel. RNA was then transferred to Hybond N nylon membranes in $10 \times \mathrm{SSC}$. The membranes were incubated at $65^{\circ} \mathrm{C}$ for $20 \mathrm{~h}$ with $2 \times 10^{7}$ d.p.m. of the ${ }^{32} \mathrm{P}$-labelled DNA probes in the hybridisation buffer $(6 \times$ SSC, $0.5 \%$ Ficoll, $0.5 \%$ PVP, $0.5 \%$ BSA, $0.5 \%$ SDS, $100 \mu \mathrm{g} \mathrm{ml}^{-1}$ herring sperm DNA). Excess probe was removed from the membrane by serial washes at $65^{\circ} \mathrm{C}$ in $1 \times \mathrm{SSC} /$ $0.1 \%$ SDS. The hybridised probes were visualised by autoradiography.

A measure of $5 \mu \mathrm{g}$ of total RNA was reverse transcribed using Superscript II RT (GIBCO-BRL) and oligo-dT in $20 \mu$ l volume as per the manufacturer's protocol. RT reactions were diluted $1: 10$ with water, and PCR was carried out as described previously (Ostrowski et al, 2003b) using $2 \mu \mathrm{l}$ of cDNAs and primers for $c$ myc. $\left[\alpha_{-}{ }^{32} \mathrm{P}\right] \mathrm{dCTP}(\mathrm{NEN})$ was used to label the PCR products. PCR products were resolved on native $5 \%$ polyacrylamide gels, then the gels were dried and the PCR products were quantified using a phosphorimager. Densitometric analysis was performed using OptiQuant $^{\mathrm{TM}}$ Image Analysis Software (Packard). The levels of band intensities after background subtraction were expressed in digital light units (DLU).

\section{Cell extracts}

Cytoplasmic and nuclear extracts were prepared as described previously (Ostrowski et al, 1991, 2000b). Separation of the nuclear fraction from the cytosol was monitored with the cytosolic enzyme marker lactic dehydrogenase and the purity of nuclear extracts was greater than $92 \%$. The protein concentration was measured using MicroBCA protein assay, Pierce Biotechnology (Rockford, IL, USA).

\section{Electrophoresis and immunoblotting}

Equal amounts of sample protein $(50 \mu \mathrm{g})$ were separated by $10 \%$ SDS - PAGE and immunostained by standard methods as described previously (Ostrowski et al, 1991, 2000b).

\section{Cell proliferation}

DNA synthesis was determined by the incorporation of ${ }^{3} \mathrm{H}$ thymidine. Exponentially growing HTC-IR cells were harvested, seeded at a density of $5 \times 10^{3}$ per well in 96-well plates and then grown in DMEM containing $10 \%$ FBS. After $24 \mathrm{~h}$, cells were made quiescent by $48 \mathrm{~h}$ serum deprivation and then they were treated with $15 \%$ FBS. Cell growth was monitored at 3, 6 and 24 by adding $0.5 \mu \mathrm{Ci}$ of ${ }^{3} \mathrm{H}$-thymidine to each well for $3 \mathrm{~h}$. Finally, cells were harvested, DNA was collected on GFC filters, and the radioactivity was determined by scintillation counting. Three independent experiments were performed and all assays were repeated in octuplicate.

Mice with spontaneous hepatocellular neoplasms and those after sham or partial hepatectomy were given $25 \mu \mathrm{Ci}$ of ${ }^{3} \mathrm{H}$-thymidine intraperitoneally $1 \mathrm{~h}$ prior to euthanasia. Hepatic DNA was extracted by proteinase $\mathrm{K}$ digestion followed by phenol-chloroform extraction, and the quantity of the DNA was measured spectrometrically. The radioactivity of $100-\mu \mathrm{g}$ samples of total hepatic DNA was determined by scintillation counting.

\section{Quantification}

Quantification analysis was performed either by photographing with a digital camera (DC40, Kodak) or scanning the intensity of the bands with an ImageScanner, Amersham Pharmacia Biotech or by scanning ${ }^{32} \mathrm{P}$ radioactivity with a Phosphorimager apparatus. Densitometric analysis was performed using OptiQuant ${ }^{\mathrm{TM}}$ Image Analysis Software (Packard).

\section{Statistical analysis}

Results are presented as means + s.d. Significant difference between mean values was assessed by means of analysis of variance (ANOVA). $P$-values for differences from control results were calculated using the Bonferroni method. Means were considered to be different if $P<0.05$.

\section{RESULTS}

\section{Expression and subcellular localisation of $\mathrm{K}$ protein from serum-treated hepatocyte culture}

The HTC-IR cells have been a useful system to study signal transduction and gene expression in hepatocyte line grown in culture (Iwamoto et al, 1981; Ostrowski et al, 2001). We used ${ }^{3} \mathrm{H}-$ thymidine uptake to test their proliferative response to serum treatment. Quiescent HTC-IR cells preincubated with ${ }^{3} \mathrm{H}$-thymidine were treated with $15 \%$ serum. At given time points, cells were harvested and ${ }^{3} \mathrm{H}$ counts were measured by scintillation counter. Results shown in Figure 1 illustrate that increased ${ }^{3} \mathrm{H}$-thymidine uptake into DNA was not seen at $6 \mathrm{~h}$, but there was a strong increase in uptake $24 \mathrm{~h}$ after serum treatment. This ${ }^{3} \mathrm{H}$-thymidine uptake kinetics is similar to studies in other hepatoma cell lines (Kadowaki and Kitagawa, 1988). These results show that the HTCIR cells are a suitable system to study mitogenic responses to serum treatment.

To test if induction of cell cultures to divide alters $\mathrm{K}$ protein expression, serum-deprived hepatoma HTC-IR cells were treated with $15 \%$ FCS. At given time points, cells were harvested and RNA and protein extracts were prepared (Figure 2). Northern blot analysis revealed two constitutively expressed $\mathrm{K}$ protein transcripts, 2.2 and $3.0 \mathrm{~kb}$. The level of expression of the longer transcript was lower. Serum treatment of resting HTC-IR cells increased the level of both transcripts. The increase was first seen after $1 \mathrm{~h}$ of stimulation, peaked at $6 \mathrm{~h}$ and decreased after $24 \mathrm{~h}$ of serum treatment (Figure 2A). At peak levels $(6 \mathrm{~h})$, there was a sixfold increase in both the short and long transcript in response to 


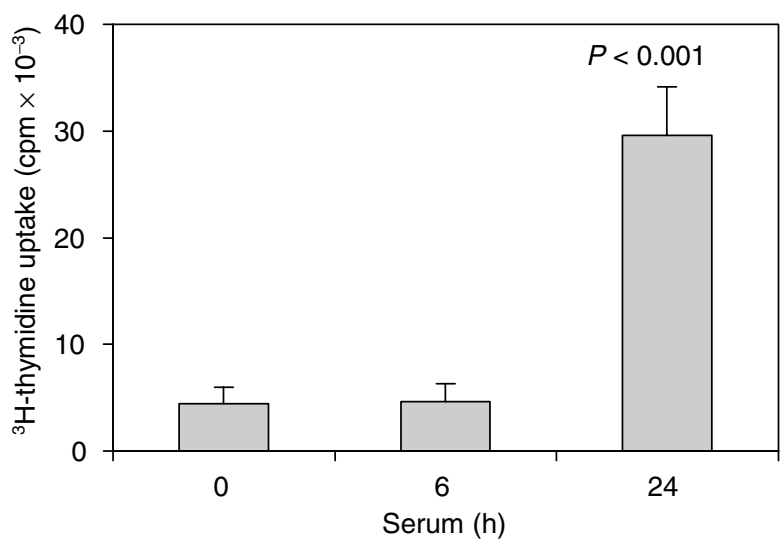

Figure I ${ }^{3} \mathrm{H}$-thymidine uptake in serum-treated hepatocytes. Cells were grown in 96 -well plates in DMEM containing $10 \%$ FBS. After $24 \mathrm{~h}$, cells were made quiescent by $48 \mathrm{~h}$ serum deprivation and then cells were either untreated ( 0 time point) or were treated with I5\% FBS for 6 or $24 \mathrm{~h}$. Cell proliferation was monitored by adding $0.5 \mu \mathrm{Ci}$ of ${ }^{3} \mathrm{H}$-thymidine to each well for another $3 \mathrm{~h}$. The radioactivity of collected cellular DNA was determined by scintillation counting. Three independent experiments were performed and the results represent means $\underline{ \pm}$ s.d. of radioactivity counts expressed in c.p.m.

serum treatment. These results demonstrate that induction of cell proliferation is associated with increased $\mathrm{K}$ protein gene expression.

Total cytoplasmic and nuclear extracts $(50 \mu \mathrm{g}$ each) were analysed by SDS-PAGE and anti-K protein immunoblotting. Western blot analysis revealed that serum treatment induced a sustained increase in $\mathrm{K}$ protein levels in both cytoplasmic and nuclear fractions (Figure 2B). The increase was far more pronounced in the nuclear fractions where $24 \mathrm{~h}$ following treatment there was a 3.6-fold increase in $\mathrm{K}$ protein levels compared to resting cells. At the same time point, $\mathrm{K}$ protein level in cytoplasmic extracts increased by $40 \%$. These results suggest that the serum-induced increase in $\mathrm{K}$ protein mRNA levels (Figure $2 \mathrm{~A}$ ) results in increased $\mathrm{K}$ protein synthesis and that most of the newly synthesised $\mathrm{K}$ protein is directed to the nucleus.

$\mathrm{K}$ protein is tyrosine phosphorylated by Src-family of kinases (Ostrowski et al, 2000a; Ostareck-Lederer et al, 2002). Serum treatment increases tyrosine phosphorylation of many proteins involved in signal transduction and gene expression (Wang, 1994). To test if $\mathrm{K}$ protein is tyrosine phosphorylated in response to a mitogenic signal, $\mathrm{K}$ protein was immunoprecipitated with anti-K protein from whole-cell lysates of quiescent and serum-treated HTC-IR cells and the immunoprecipitates were analysed by antiphosphotyrosine and anti-K protein immunoblots (Figure 2C). There was constitutive tyrosine phosphorylation of $\mathrm{K}$ protein in quiescent cells, and following serum treatment the level of tyrosine phosphorylation of $\mathrm{K}$ protein increased transiently. Serum treatment increased the total amount of immunoprecipitated $\mathrm{K}$ protein, but unlike tyrosine phosphorylation this increase was sustained. The increased level of immunoprecipitated $\mathrm{K}$ protein from total cell lysates largely reflects the increase in nuclear $\mathrm{K}$ protein (Figure 2B).

\section{Expression and subcellular distribution of $\mathrm{K}$ protein in injured livers}

Partial hepatectomy leads to hepatic regeneration resulting in almost complete restoration of the liver mass (Taub, 1996). The mechanisms initiating and controlling hepatocyte 'priming' involve activation of several nonspecific factors in the initiating phase. These cellular events include increased $\mathrm{Na}^{+}$flux into the
A
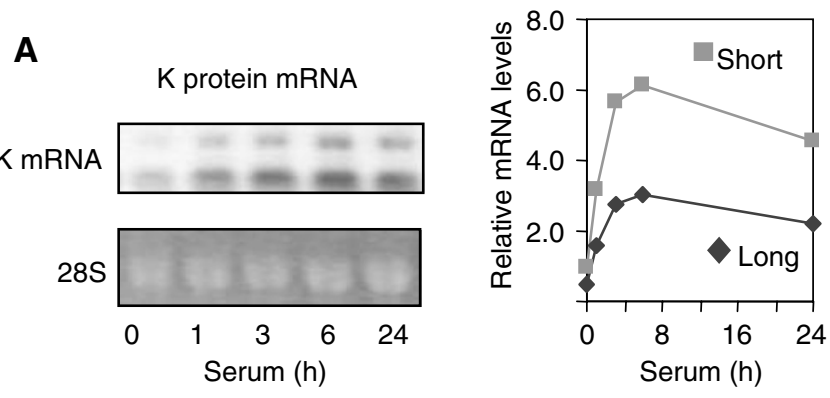

B
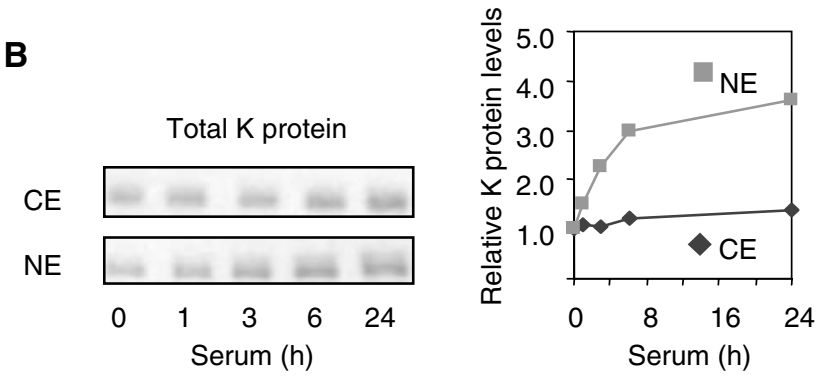

C

Tyrosine phosphorylation
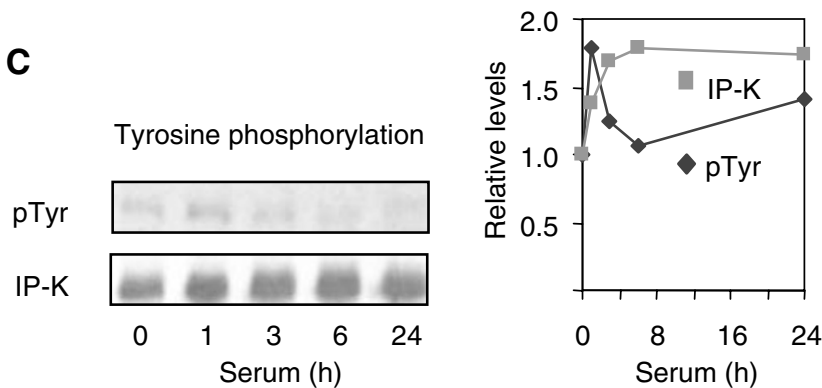

Figure 2 K protein expression in serum-treated hepatocytes. After $48 \mathrm{~h}$ of serum deprivation, HTC-IR cells were treated with I5\% FCS. At given time points, cells were harvested, and total RNA and proteins as well as nuclear and cytoplasmic proteins were extracted. (A) Total RNA was electrophoresed in a 1\% agarose/formaldehyde gel and RNA was visualised with ethidium bromide and photographed with digital camera (DC40, Kodak). After RNA transfer, the nylon membranes were probed with ${ }^{32} \mathrm{P}$ labelled $\mathrm{K}$ protein $\mathrm{CDNA}$. Autoradiographs were photographed with a digital camera (DC40, Kodak). Densitometric analysis was carried out using OptiQuant ${ }^{T M}$ Image Analysis Software (Packard meriden, CT, USA). The mRNA levels shown in the graph were normalised to the levels of 28S. (B) Protein extracts were resolved by SDS-PAGE followed by Western blotting with anti-K protein antibody. Blots were scanned, and densitometric analysis of $K$ protein bands was performed using OptiQuant ${ }^{T M}$ Image Analysis Software. (C) Anti-K protein immunoprecipitates from total cell extracts $(300 \mu \mathrm{g}$ protein) were resolved by SDS-PAGE and immnunobloting was performed with either anti-phosphotyrosine (PTyr) or anti-K protein $(K)$ antibodies. Densitometric analysis was done as in (B).

cells, elevation in cAMP content, activation of ornithine decarboxylase and $\mathrm{Na}^{+} / \mathrm{K}^{+}$-ATPase, expression of and response to growth factors and cytokines, activation of transcription factors (NF- $\kappa \mathrm{B}$, Stat-3, AP-1, C/EBP- $\beta$ ) and induction of immediate-early genes (e.g. c-fos, c-jun, c-myc) (Taub, 1996; Rozga, 2002; Zimmermann, 2002).

${ }^{3} \mathrm{H}$-thymidine uptake into the DNA was used to assess hepatocyte proliferation following partial hepatectomy. Mice were anaesthetised, and after laparatomy in one group of animals the livers were left alone (sham operated), while in the other group the left lobe of the liver was removed (30\% hepatectomy)-partial hepatectomy group. Abdominal cavities were closed and the animals were allowed to recover from the ether anaesthesia. At $1 \mathrm{~h}$ prior to harvesting the livers, mice were injected with 
${ }^{3} \mathrm{H}$-thymidine, animals were again ether anaesthetised and the livers were removed. As shown in Figure $3 \mathrm{~A}$, at $6 \mathrm{~h}$ following surgery, no differences in ${ }^{3} \mathrm{H}$-thymidine uptake into the livers were seen between sham and partial hepatectomy animals. In contrast, hepatic DNA synthesis was induced $24 \mathrm{~h}$ after partial hepatectomy, but no increase was seen in the control sham-operated mice. Expression of proliferating cell nuclear antigen (PCNA) correlates well with hepatocyte proliferation (Wolf and Michalopoulos, 1992). Proliferating cell nuclear antigen protein levels were determined in liver lysates at 6 and $24 \mathrm{~h}$ following surgery by immunoblot analysis. A representative blot is presented as an inset in Figure $3 \mathrm{~A}$. Not unexpectedly, the increase in the partial hepatectomy-induced DNA synthesis was mirrored by the increased PCNA expression. Liver lysates contain proteins from hepatocytes and other cell types. Thus, next we did PCNA immunocytochemistry of the livers from either sham-operated animals or animals following partial hepatectomy that allows direct visualisation of hepatocytes. In sham-operated mice there was little or no PCNA detected. In contrast, there was very strong nuclear PCNA staining of hepatocytes $24 \mathrm{~h}$ following partial hepatectomy (Figure 3B). These observations are consistent with previous partial hepatectomy studies carried out in rats and mice where DNA synthesis occurred

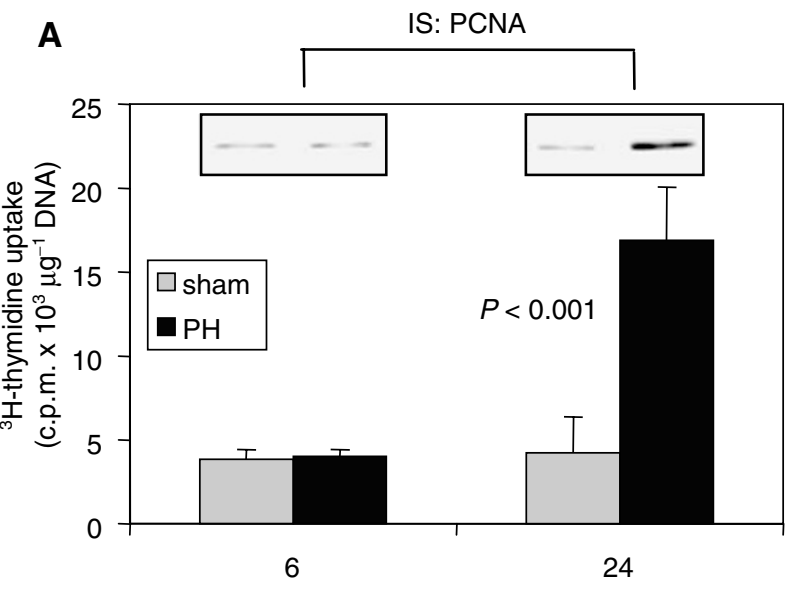

Hours after partial hepatectomy
B

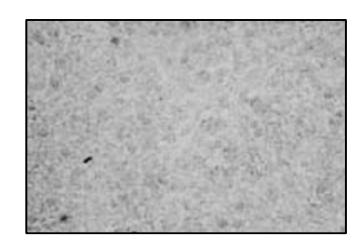

$\mathrm{PH}$

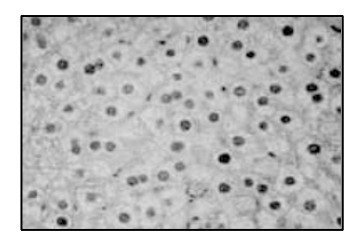

IS: anti-PCNA

Figure 3 Cell proliferation indices in liver after partial hepatectomy of anaesthetised mice. (A) Mice after sham or partial hepatectomy (PH) (three animals in each group at 6 and $24 \mathrm{~h}$ after surgery) were given $25 \mu \mathrm{Ci}$ of ${ }^{3} \mathrm{H}$-thymidine intraperitoneally I $\mathrm{h}$ prior to euthanasia. The livers were harvested, hepatic DNA was extracted and the radioactivity of $100-\mu \mathrm{g}$ samples of total hepatic DNA was determined by scintillation counting. Total DNA was measured using a spectrophotometer. The results represent means \pm s.d. of radioactivity counts expressed in c.p.m. $\mu \mathrm{g}^{-1}$ DNA. The insets represent Western blot analysis of PCNA in liver lysates. (B) Immunocytochemistry of the liver tissues was performed as previously described (Kupryjanczyk et al, 2003). Briefly, portions of the liver tissues from sham-operated mice and animals following $\mathrm{PH}$ (24h) were embedded in paraffin. After heat-induced epitope retrieval, sections were incubated with anti-PCNA antibody ( $1: 4000$, Santa Cruz) for I h at room temperature. Biotinylated goat anti-mouse IgG was used as a detection system. in a single peak $18-24 \mathrm{~h}$ after resection (Lambotte et al, 1997; Freeman et al, 1999).

As partial hepatectomy is an excellent model of cellular proliferation in an intact organ, we used it to correlate changes in cell proliferation with $\mathrm{K}$ protein expression and subcellular distribution in this system (Figure 4). Mice were anaesthetised, and after laparatomy the left lobe of the liver was removed $(30 \%$ hepatectomy) and rapidly frozen. Abdominal cavities were closed and the animals were allowed to recover from the ether anaesthesia. At given time points, mice were again ether anaesthetised and the remnant livers were harvested and rapidly frozen. Total RNA, total cell lysates, cytoplasmic and nuclear extracts were prepared from the resected lobes and from the remnant livers. All analyses presented were carried out by

A $\mathrm{K}$ protein mRNA levels
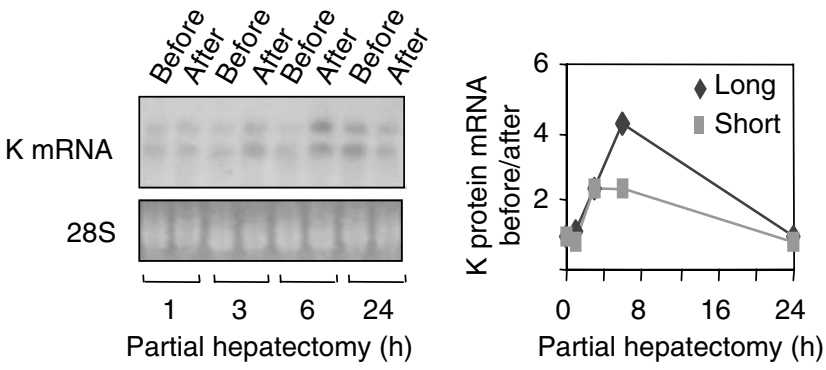

B

Total K protein
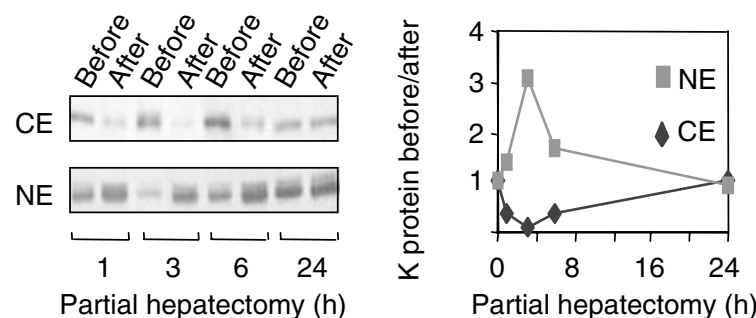

Tyrosine phosphorylation
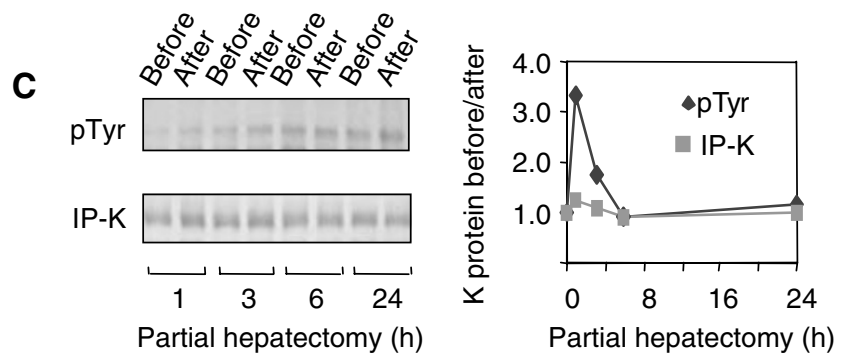

Figure $4 \mathrm{~K}$ protein expression after partial hepatectomy in mice. (A) Total RNA was extracted from resected lobes (before) and from the remnant livers (after). Northern blots were probed with ${ }^{32} \mathrm{P}$-labelled $\mathrm{K}$ protein cDNA. The slower (long) and the faster (short) K protein mRNA transcripts (upper gel) were analysed by densinometry. The intensity of the $\mathrm{K}$ protein mRNA bands was normalised to the levels of 28S RNA (lower gel). The results in the graph are expressed as a ratio of levels after (after) to before (before) partial hepatectomy. (B and $\mathbf{C}$ ) Protein extracts prepared from livers before and after partial hepatectomy were analysed by anti-K protein Western blots as in Figure I. Results are expressed as a ratio of levels measured after (after) and before (before) partial hepatectomy of the same liver. (B) Levels of $\mathrm{K}$ protein in cytoplasmic (CE) and nuclear (NE) extracts. (C) Anti-K protein immunoprecipitates from whole-cell lysates analysed with anti-phosphotyrosine (pTyr) and antiK protein (K) antibody. 
comparing levels in the remnant liver to the levels measured in the resected lobe of the same animal (Figure 4).

As in case of HTC-IR cells (Figure 2A), Northern blot analysis showed that in an intact liver there is constitutive expression of the two transcripts of $\mathrm{K}$ protein (Figure 4A). The level of both transcripts increased after resection, a change first seen in the remnant liver $3 \mathrm{~h}$ after resection; the peak effect occurred at $6 \mathrm{~h}$ and the mRNA levels came down to baseline $24 \mathrm{~h}$ postpartial hepatectomy. These results show transient increase in $\mathrm{K}$ protein mRNA levels that is associated with cell proliferation in vivo.

Western blot analysis revealed that there was a transient increase in nuclear $\mathrm{K}$ protein, with peak levels (three-fold increase) seen $3 \mathrm{~h}$ postpartial hepatectomy (Figure 4B). Concurrently, there was a decrease in cytoplasmic $\mathrm{K}$ protein levels. At $24 \mathrm{~h}$ postpartial hepatectomy, the levels of $\mathrm{K}$ protein in the cytoplasmic and nuclear extracts from remnant livers returned to baseline. These results revealed that following partial hepatectomy, there is nuclear translocation of $\mathrm{K}$ protein from the cytoplasm.

Liver injury activates tyrosine kinases leading to phosphorylation of such key factors as the cyclins (Diehl and Rai, 1996; Spiewak Rinaudo and Thorgeirsson, 1997). We used immunoprecipitation assays to assess whether partial hepatectomy alters the level of tyrosine phosphorylation of $\mathrm{K}$ protein (Figure 4C). Antiphosphotyrosine blots of $\mathrm{K}$ protein immunoprecipitations showed that in the intact liver there is constitutive tyrosine phosphorylation of $\mathrm{K}$ protein. Liver resection induced a transient increase in the level of $\mathrm{K}$ protein tyrosine phosphorylation, with the peak effect (3.5-fold increase) observed in the remnant liver $1 \mathrm{~h}$ after resection (Figure $4 \mathrm{C}$, pTyr). Since $\mathrm{K}$ protein transcripts were transiently induced postpartial hepatectomy (Figure 4A), it was surprising to see that the level of $\mathrm{K}$ protein immunoprecipitated from total cell lysates from remnant livers did not change appreciably (Figure 4C, IP-K).

\section{Expression and subcellular distribution of $\mathrm{K}$ protein in hepatic neoplasms}

CBA-T6/W mice develop spontaneous liver tumours including hepatocellular adenoma and carcinoma (Ostrowski et al, 2000c). To assess the rates of proliferation of these tumours, we again used ${ }^{3} \mathrm{H}$-thymidine incorporation (Figure 5). At $1 \mathrm{~h}$ after injecting ${ }^{3} \mathrm{H}$ thymidine, mice were ether anaesthetised, the livers were resected and carcinomas were dissected out from the normal liver parenchyma. DNA was purified from normal and cancer tissue

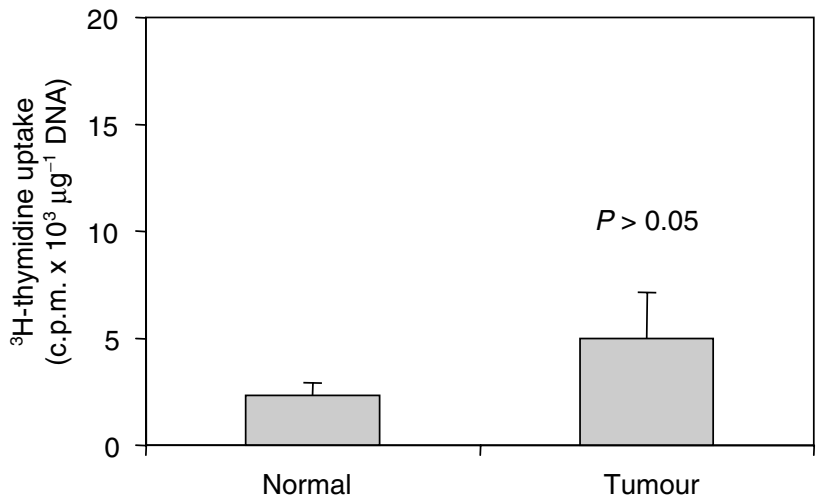

Figure $5{ }^{3} \mathrm{H}$-thymidine uptake in mouse spontaneous hepatic adenocarcinoma hepatocellular carcinomas. Mice harbouring spontaneous hepatocellular carcinomas (five animals) were given $25 \mu \mathrm{Ci}$ of ${ }^{3} \mathrm{H}$-thymidine intraperitoneally I $\mathrm{h}$ prior to euthanasia. The livers were harvested and hepatic DNA was extracted from the liver tumours and from the normal surrounding tissues. Radioactivity of $100-\mu \mathrm{g}$ samples of total hepatic DNA was determined by scintillation counting. The results represent means \pm s.d. $(n=5)$ of radioactivity counts expressed in c.p.m $\mu \mathrm{g}^{-1}$ DNA. and ${ }^{3} \mathrm{H}$ counts were assessed as before. A part of the resected tissue was used for histology. Although ${ }^{3} \mathrm{H}$-thymidine incorporation tended to be higher in hepatocellular carcinomas than in the surrounding histologically normal hepatic tissue, these differences were not statistically significant. This is not surprising since these tumours are slow growing (Szymanska, 1991).

We used the mice with hepatocellular carcinoma to assess $\mathrm{K}$ protein expression and its subcellular distribution. The Livers harbouring tumours were resected from anaesthetised mice and carcinomas were dissected out from the normal liver parenchyma. As before, a part of the resected tissue was used for histology and the rest was rapidly frozen. Figure 6 shows finding in three animals with hepatocellular carcinoma. Northern blot analysis revealed two transcripts, and in all three animals the levels of $\mathrm{K}$ protein mRNA

A $\mathrm{K}$ protein mRNA

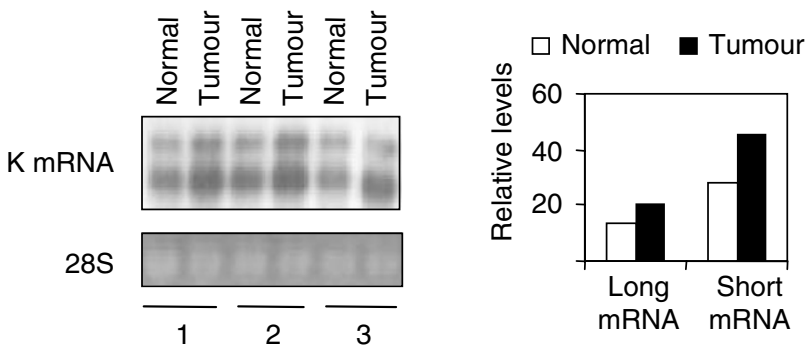

B

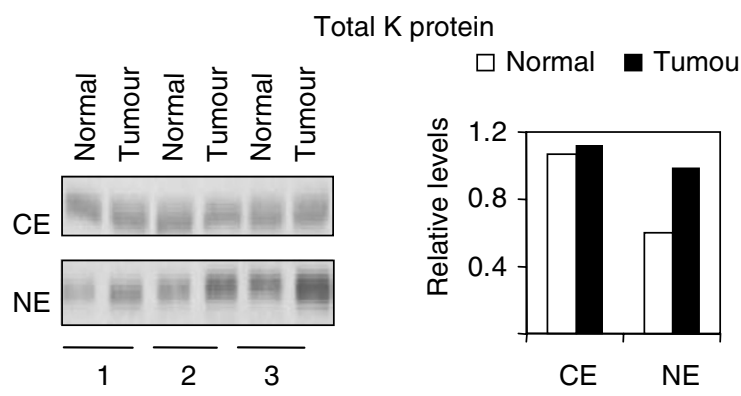

C

pTyr K protein
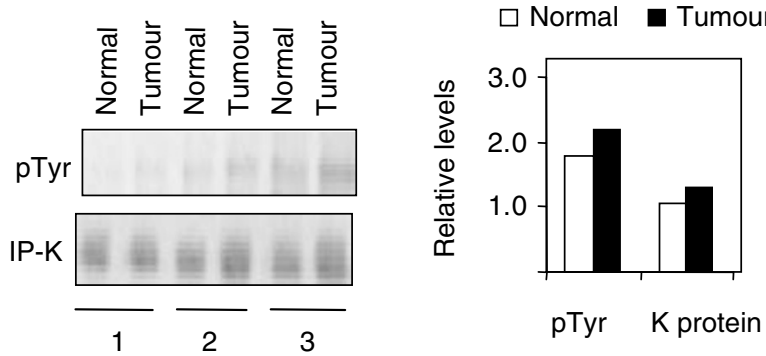

Figure $6 \mathrm{~K}$ protein expression in spontaneous hepatic adenocarcinoma in mice. (A) Total RNA was extracted from hepatic adenocarcinoma and the livers harbouring these tumours. Northern blots were probed with ${ }^{32} \mathrm{P}$ labelled K protein cDNA. The slower (long) and the faster (short) K protein mRNA transcripts (upper gel) were analysed by densinometry. The intensity of the $\mathrm{K}$ protein mRNA bands was normalised to the levels of $28 \mathrm{~S}$ RNA (lower gel). The results in the graph are expressed as a ratio of levels measured in the adenocarcinoma (tumour) and those measured in the liver (normal) harbouring the tumour. (B and $\mathbf{C}$ ) Protein extracts prepared from liver adenocarcinomas (tumour) and normal liver tissue (normal) surrounding these tumours were analysed by anti-K protein Western blots as in Figure I. Results are expressed as the ratio of levels measured in the tumour (tumour) and those in the normal parenchyma (normal) of the same liver. (B) Levels of K protein in cytoplasmic (CE) and nuclear (NE) extracts. (C) Anti-K protein immunoprecipitates from whole-tissue extracts analysed with anti-phosphotyrosine (pTyr) and anti-K protein (K) antibody. 
were higher in the tumour than in the surrounding normal parenchyma (Figure 6A). The increased $\mathrm{K}$ protein mRNA levels in cancer is consistent with the findings in serum-treated HTC-IR (Figure 2A) and in livers postpartial hepatectomy (Figure 4A).

In further agreement with the other results (Figures 2 and 4), Western blots showed that in all the three animals the level of $\mathrm{K}$ protein in nuclear extracts was higher in the tumour than in the normal liver harbouring these cancers (an average 66\% higher in the tumour) (Figure 4B). In contrast, the levels of $\mathrm{K}$ protein in cytoplasmic extracts from cancer were not different from the normal parenchyma. In all the three animals, the level of tyrosine phosphorylation of $\mathrm{K}$ protein in the tumours was higher than in the normal liver (average 20\% difference), but in part this might be explained by the slightly higher levels of $\mathrm{K}$ protein immunoprecipitated from the cancer (Figure 6C).

We also assessed $\mathrm{K}$ protein expression and subcellular distribution in hepatic adenoma (seven animals) and in L1 sarcoma implanted into liver (six animals) (Figure 7). The level of $\mathrm{K}$ protein in the cytoplasmic extracts from liver adenomas was the same as in the adjacent normal parenchyma (Figure 7A, CE). In six out of seven animals, the level of nuclear $\mathrm{K}$ protein was higher in the hepatic adenomas compared to the normal liver parenchyma surrounding the tumours (Figure 7A, NE). On an average, the level of $\mathrm{K}$ protein in the adenomas was $38 \%$ higher than in normal tissues. In the implanted sarcomas, which are more aggressive tumours, in all the six animals the level of nuclear $\mathrm{K}$ protein was higher than in the nuclear extracts from livers harbouring these tumours (Figure 7B). On an average, K protein levels in the nuclear extracts from sarcomas was 2.5 -fold higher than those measured in nuclear extracts from normal liver parenchyma adjacent to these tumours. As in the hepatocellular neoplasms (Figures 6 and 7A), the levels of $\mathrm{K}$ protein in cytoplasmic extracts from sarcomas and normal liver tissues were not different (Figure 7B).
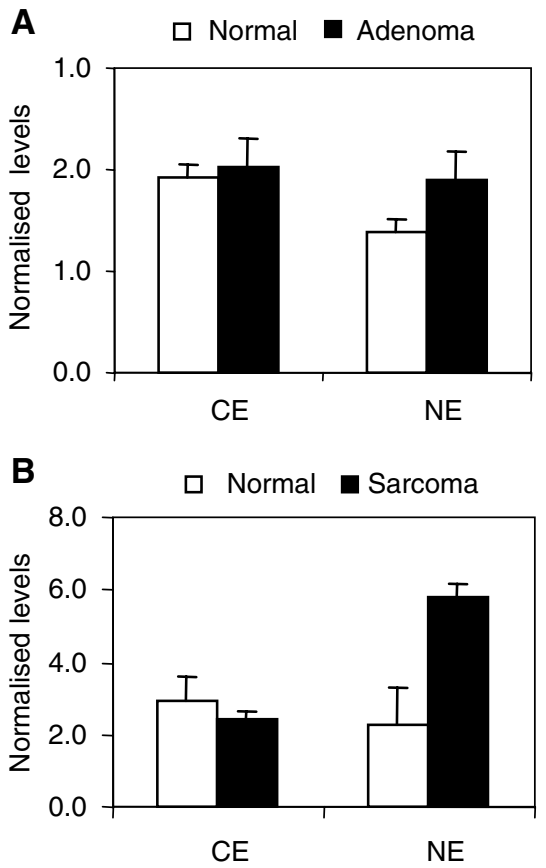

Figure 7 Expression of $K$ protein in spontaneous adenomas and implanted sarcomas in mouse livers. Cytoplasmic (CE) and nuclear (NE) extracts were prepared from spontaneous liver adenomas (adenoma), implanted sarcomas (sarcoma) and normal liver parenchyma (normal) surrounding these tumours. Levels of $\mathrm{K}$ protein were analysed in Western blots as in Figure I. Results are expressed as the ratio of levels measured in the tumour (tumour) and those in the normal tissue (normal) of the same liver.

\section{Activation of c-myc gene expression in serum-treated HTC-IR cells, in injured livers and liver tumours}

Mitogenic stimulation leads to rapid induction of immediate-early genes (Herschman, 1991). Immediate-early genes are activated in a protein synthesis-independent manner and are involved in cell proliferation (Jochum et al, 2001). They regulate later phases in $G_{1}$ of the cell cycle and represent diverse classes of genes including those encoding transcription factors, $c-m y c$ is one of the immediate-early genes, whose expression is transiently increased in $\mathrm{G}_{1}$. c-myc encodes a transcription factor that targets a host of genes that regulate cell proliferation (Bouchard et al, 1998). With regard to the liver, antisense oligomer to $c-m y c$ can reduce cell proliferation in the regenerating rat liver, suggesting that expression of this gene plays a role in the process of regeneration (Arora et al, 2000). In response to serum treatment, $\mathrm{K}$ protein is recruited to multiple sites along the c-myc locus (Ostrowski et al, 2003a). In gene reporter systems, $\mathrm{K}$ protein was shown to regulate c-myc promoter (Michelotti et al, 1995, 1996) and translational elements activity (Evans et al, 2003). Studies in breast carcinoma lines suggested that increased expression of $\mathrm{K}$ protein enhanced $\mathrm{c}$ Myc levels (Mandal et al, 2001). Taken together, these studies suggest that $\mathrm{K}$ protein regulates $\mathrm{c}-m y c$ gene expression on both transcriptional and post-transcriptional levels.

We next compared semiquantitative RT - PCR analysis of RNA in serum-treated HTC-IR cells, in resected livers and in hepatic tumours to correlate $\mathrm{c}-m y c$ transcript levels with $\mathrm{K}$ protein expression in these models (Figure 8). Treatment of serum-starved HTC-IR cells rapidly induced the c-myc expression (Figure 8A), with a peak in $c-m y c$ expression seen at $1 \mathrm{~h}$ after serum treatment. This time course is similar to the kinetics of serum-induced transient recruitment of $\mathrm{K}$ protein to the promoter and transcribed region of the c-myc locus in these cells (Ostrowski et al, 2003a). The kinetics of c-myc mRNA expression after partial hepatectomy (Figure 8B) was similar to that seen in cultured serum-treated hepatocytes in vitro; a large peak in c-myc transcript levels was seen at $1 \mathrm{~h}$ following partial resection, and its level declined nearly to baseline at $6 \mathrm{~h}$. These $\mathrm{c}-m y c$ results are similar to the studies published by others (Taub et al, 1987). Similarly, there was also increased c-myc transcript expression in hepatocellular carcinoma compared to normal tissue, that is, an eight-fold higher levels (Figure 8C).

\section{DISCUSSION}

Treatment of resting HTC-IR cells with serum resulted in sustained increase in nuclear $\mathrm{K}$ protein with little changes in cytoplasmic $\mathrm{K}$ protein (Figure 2B). Similar observations were made in hepatic tumours (Figures $6 \mathrm{~B}$ and 7 ). While the levels of $\mathrm{K}$ protein in nuclear extracts were higher in the neoplasms compared to the adjacent normal parenchyma, the levels of $\mathrm{K}$ protein in the cytoplasmic fractions were the same in the neoplastic and the normal surrounding tissues. Serum-treated HTC-IR cells and tumours represent sustained states of enhanced cell proliferation. In contrast, following partial hepatectomy, the number of cycles of cell division is limited. Within minutes after partial hepatectomy, quiescent liver cells in the remaining lobes enter a state of replicative competence (an initiation phase), followed by a proliferation phase and, finally, by a termination phase (Zimmermann, 2002). Thus, it is not surprising that postpartial hepatectomy there was only a transient nuclear shift of $\mathrm{K}$ protein that peaked at $3 \mathrm{~h}$ following liver injury and by $6 \mathrm{~h}$ it was near baseline. The kinetics of the nuclear shift of $\mathrm{K}$ protein in response to serum treatment and following liver injury provides some clues regarding the consequences of this effect. In response to serum treatment, $\mathrm{K}$ protein is recruited to multiple sites along the c-myc locus including both the promoter and the transcribed regions (Ostrowski et al, 2003a). K protein binds in vitro CT-rich DNA 
A
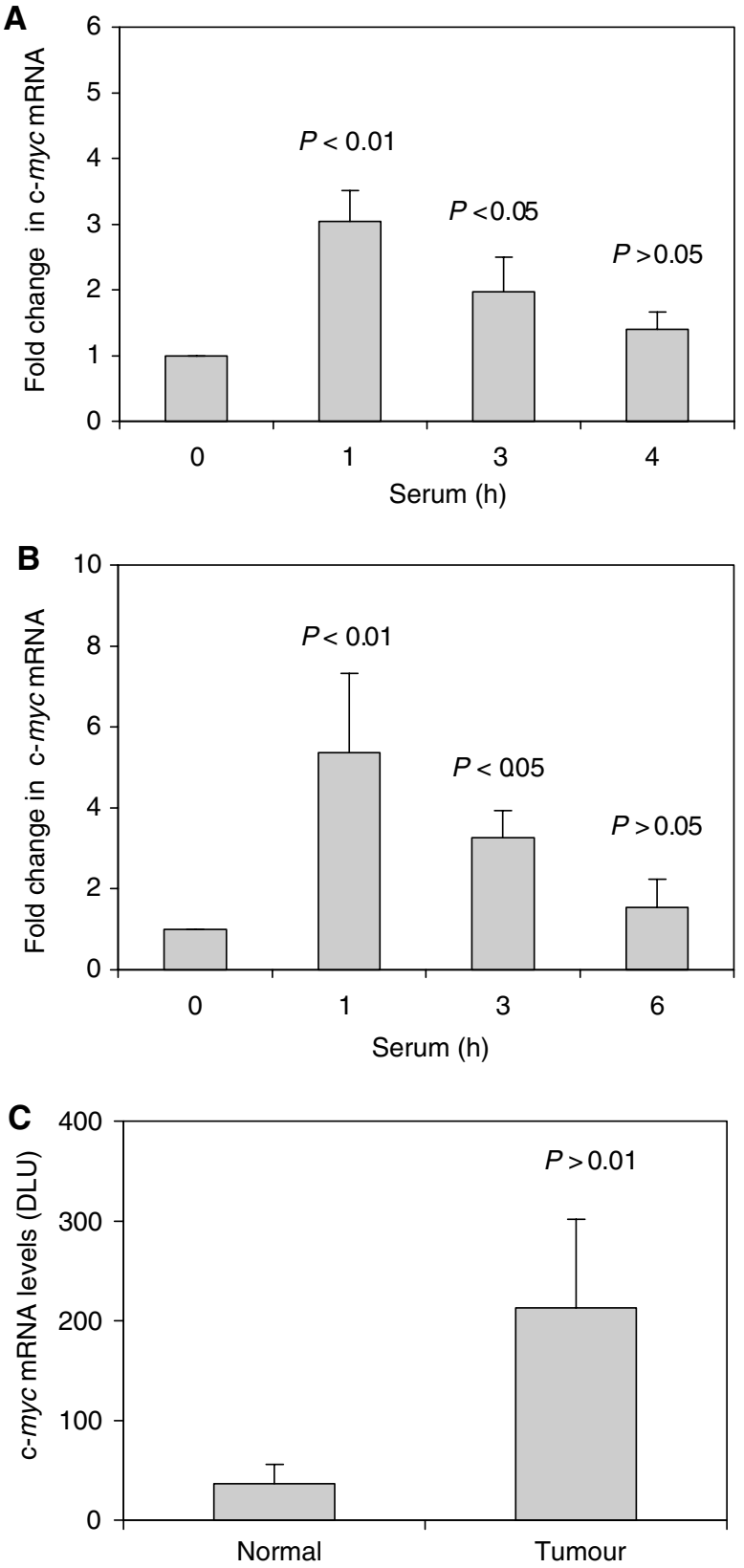

Figure 8 c-myc mRNA transcript levels in serum-treated hepatocyte cultures $(\mathbf{A})$, postpartial hepatectomy $(\mathbf{B})$ and in hepatic tumours $(\mathbf{C})$. (A) Serum-deprived HTC-IR cells were treated with I5\% FBS for 0, I, 3, 6 and $24 \mathrm{~h}$. After harvesting the cells, total RNA was isolated and used in RT. PCR was carried out using $\left[\alpha^{32} \mathrm{P}\right] \mathrm{dCTP}(0.5 \mu \mathrm{Ci}$ per reaction $)$ and c-myc primers (forward: GCAAATGCTCCAGCCCCAGGTC; reverse: AGTCCCAAAGCCCCAGCCAAGGTT). PCR products were resolved by native PAGE and were quantified using a phosphorimager (Cyclone, Packard meriden, CT, USA). Results are expressed as fold increase in the mRNA level at each time point of serum treatment compared to the levels seen in untreated cells. The values represent means \pm s.d. $(n=3)$. (B) Partial hepatectomy and control sham operation were carried out as in Figure 3. At given time points following surgery, the livers were harvested from each group and total RNA was isolated (three animals for each time point), cmyc mRNA levels were determined by RT-PCR as above. Results are expressed as fold increase in mRNA levels compared to sham-operated mice. (C) Comparison of c-myc mRNA levels in spontaneous hepatocellular carcinoma and the normal surrounding liver tissue, c-myc mRNA levels were determined by RT-PCR and the ${ }^{32} \mathrm{P}$ signal of the labelled products is expressed in DLU. The results represent means \pm s.d. $(n=5$ animals $)$. from the c-myc promoter (Michelotti et al, 1995) and activates c$m y c$ promoter activity in several types of cells including breast cancer (Michelotti et al, 1996; Mandal et al, 2001). Here, we have shown that c-myc expression is activated in hepatocyte culture in response to mitogens and following liver injury (Figure 8A and $\mathrm{B}$ ). Taken together, these results suggest that at an early time point following liver injury $\mathrm{K}$ protein may play a role in the induction of c-myc gene. Expression of c-fos and egr-1 is also activated in remnant liver following partial hepatectomy (Taub, 1996). Promoters of both c-fos and egr-1 genes contain putative CT-like $\mathrm{K}$ protein-binding motifs, and in response to serum treatment of hepatocyte culture $\mathrm{K}$ protein is recruited to both egr-1 (Ostrowski et al, 2003a) and c-fos (unpublished observations) loci. It is, therefore, plausible that the role of the $\mathrm{K}$ protein fraction that is newly directed to the nucleus in remnant livers is to regulate transcription of these immediate-early genes and other factors that mediate the enhanced cell proliferation during an initiation (prereplicative) phase. Here, the increase in the level of tyrosine phosphorylation of $\mathrm{K}$ protein (Figure $4 \mathrm{C}$ ) may play a role in its nuclear translocation and/or its recruitment to inducible transcribed gene loci such as the immediate-early genes (Ostrowski et al, 2003a).

Increased $\mathrm{K}$ protein expression has previously been found in breast cancer cells. In that study, the authors provide evidence that the increased $\mathrm{K}$ protein levels contribute to the enhanced c-myc gene expression in these tumours (Mandal et al, 2001). The current study demonstrates for the first time that there is a nuclear shift of $\mathrm{K}$ protein in hepatic neoplasm and other states of enhanced proliferation. As discussed above, there is considerable evidence that $\mathrm{K}$ protein regulates $\mathrm{c}-m y c$ gene expression, so the increased level of $K$ protein in the nucleus seen in tumours (Figures 6 and 7) may play a role in enhanced expression of this immediate-early gene in malignancy. $\mathrm{K}$ protein binding appears to be genomewide, where it exhibits both constitutive and inducible interactions with chromatin (Ostrowski et al, 2003a). Some of these interactions may reflect direct binding of $\mathrm{K}$ protein to DNA. However, $\mathrm{K}$ protein binds many proteins, DNA and RNA (Bomsztyk et al, 1997). Some of the $\mathrm{K}$ protein partners are recruited to transcribed loci by interacting with DNA, transcriptionally active complexes or with nascent RNA. One or more of these $K$ protein interactions could be responsible for the recruitment of $\mathrm{K}$ protein to chromatin by an indirect mechanism. Thus, the nuclear shift of $\mathrm{K}$ protein in tumours (Figures 6 and 7) may reflect its involvement in multiple DNA- and/or RNA-directed processes that are altered in malignancies. With respect to nuclear $\mathrm{K}$ shift in cancer, two nuclear processes seem relevant to consider. First, cisplatin cross-linking in human breast cancer cells revealed that $\mathrm{K}$ protein is one of the nuclear matrix proteins (Samuel et al, 1998). The key role of nuclear matrix is to organise the chromatin topology so that it can serve as a conducive template for transcription and replication. Although much remains to be learned, abnormal nuclear matrix is one of the morphologic hallmarks of cancer (Leman and Getzenberg, 2002). Thus, the nuclear shift of $\mathrm{K}$ may reflect, in part, altered protein composition of nuclear matrix in cancer. If so, the ability of cisplatin to cross-link K protein to DNA may be one of the mechanisms by which this chemotherapeutic agent inhibits processes that compose transcription and replication (Samuel et al, 1998). Second, $K$ and other hnRNP proteins bind mammalian telomeric sequences (Lacroix et al, 2000; Ford et al, 2002) and Saccharomyces cerevisiae $\mathrm{K}$ protein-like genes regulate telomeric processes (Denisenko and Bomsztyk, 2002). These observations suggest that $\mathrm{K}$ protein may be involved in maintaining the integrity of mammalian telomeres. Preservation of telomere length which, in part, results from reactivation of telomerase is another hallmark of continuous cells growth, especially of advanced malignancies (Neumann and Reddel, 2002). The increased nuclear levels of $\mathrm{K}$ protein may play a role in the altered telomeric processes seen in cancer. 
In summary, we have demonstrated that in several states of enhanced cell proliferation, there are increased $\mathrm{K}$ protein levels in the nucleus. Induction of cell proliferation results in the activation of a large repertoire of genes (Iyer et al, 1999). K protein is an abundant factor involved in transcription, mRNA processing and other events that compose gene expression. It is likely that the increased $\mathrm{K}$ protein levels seen in the nuclei of the proliferating cells serve to support nuclear process that not only composes inducible expression of a very large number genes but also maintains conducive chromatin topology in growing cells.

\section{REFERENCES}

Arora V, Knapp DC, Smith BL, Statdfield ML, Stein DA, Reddy MT, Weller DD, Iversen PL (2000) c-Myc antisense limits rat liver regeneration and indicates role for c-Myc in regulating cytochrome $P-4503 \mathrm{~A}$ activity. $J$ Pharmacol Exp Ther 292: 921 -928

Bomsztyk K, Van Seuningen I, Suzuki H, Denisenko O, Ostrowski J (1997) Diverse molecular interactions of the hnRNP K protein. FEBS Lett 403: $113-115$

Bouchard C, Staller P, Eilers M (1998) Control of cell proliferation by Myc. Trends Cell Biol 8: 202-206

Bustelo XR, Suen K-I, Michael WM, Dreyfuss G, Barbacid M (1995) Association of the vav proto-oncogene product with poly(rC)-specific RNA-binding proteins. Mol Cell Biol 15: 1324-1332

Charroux B, Angelats C, Fasano L, Kerridge S, Vola C (1999) The levels of the bancal product, a Drosophila homologue of vertebrate hnRNP K protein, affect cell proliferation and apoptpsis in imaginal disc cells. Mol Cell Biol 19: $7846-7856$

Dejgaard K, Leffers H, Rasmussen HH, Madsen P, Kruse TA, Gesser B, Nilesen H, Celis JE (1994) Identification, molecular cloning, expression and chromosome mapping of a family of transformation upregulated hnRNP-K proteins derived by alternative splicing. J Mol Biol 236: $33-48$

Denisenko ON, Bomsztyk K (1997) The product of murine homolog of the Drosophila extra sex comb gene displays transcriptional repressor activity. Mol Cell Biol 17: 4707-4717

Denisenko ON, Bomsztyk K (2002) Yeast hnRNP K-like genes are involved in regulation of the telomeric position effect and telomere length. Mol Cell Biol 22: $286-297$

Diehl AM, Rai RM (1996) Liver regeneration 3: regulation of signal transduction during liver regeneration. FASEB J 10: 215-227

Du W, Thanos D, Maniatis T (1993) Mechanism of transcriptional synergism between distinct virus-inducible enhancer elements. Cell 74: $887-898$

Evans JR, Mitchell SA, Spriggs K, Ostrowski J, Bomsztyk K, Ostarek D, Willis AE (2003) Members of the poly ( $\mathrm{rC}$ ) binding protein family stimulate the activity of the c-myc internal ribosome entry segment in vitro and in vivo. Oncogene, (in press)

Ford LP, Wright WE, Shay JW (2002) A model for heterogeneous nuclear ribonucleoproteins in telomere and telomerase regulation. Oncogene 21: $580-583$

Freeman TL, Ngo HQ, Mailliard ME (1999) Inhibition of system A amino acid transport and hepatocyte proliferation following partial hepatectomy in the rat. Hepatology 30: 437-444

Gates J, Thummel CS (2000) An enhancer trap screen for ecdysoneinducible genes required for Drosophila adult leg morphogenesis. Genetics 156: 1765 - 1776

Herschman HR (1991) Primary response genes induced by growth factors and tumor promoters. Annu Rev Biochem 60: $281-319$

Iwamoto Y, Wong KY, Goldfine ID (1981) Insulin action in cultured HTC and $\mathrm{H} 35$ rat hepatoma cells: receptor binding and hormone sensitivity. Endocrinology 108: 44-51

Iyer VR, Eisen MB, Ross DT, Schuler G, Moore T, Lee JCF, Trent JM, Staudt LM, Hudson Jr J, Boguski MS, Lashkari D, Shalon D, Botstein D, Brown PO (1999) The transcriptional program in the response of human fibroblasts to serum. Science 283: $83-87$

Jochum W, Passegue E, Wagner EF (2001) AP-1 in mouse development and tumorigenesis. Oncogene 20: $2401-2412$

Kadowaki T, Kitagawa Y (1988) Enhanced transcription of mitochondrial genes after growth stimulation and glucocorticoid treatment of Reuber hepatoma H-35. FEBS Lett 233: 51-56

\section{ACKNOWLEDGEMENTS}

We thank Piotr Kowalczyk and Marek Woszczynski for expert technical assistance. We wish to thank Dr Jolanta Kupryjanczyk for the PCNA immunocytochemistry. The study was supported by NIH Fogarty International Research Collaboration Award (FIRCA) TW05685, the CMKP Grant 501-2-2-08-94/00 and by the Foundation for Polish Science grant (IMMUNO 6/99).

Kupryjanczyk J, Szymanska T, Madry R, Timorek A, Stelmachow J Karpinska G, Rembiszewska A, Ziolkowska I, Kraszewska E, Debniak J, Emerich J, Ulanska M, Pluzanska A, Jedryka M, Goluda M, ChudeckaGlaz A, Rzepka-Gorska I, Klimek M, Urbanski K, Breborowicz J, Zielinski J, Markowska J (2003) Evaluation of clinical significance of TP53, BCL-2, BAX and MEK1 expression in 229 ovarian carcinomas treated with platinum-based regimen. Br J Cancer 88: 848-854

Lacroix L, Lienard H, Labourier E, Djavaheri-Mergny M, Lacoste J, Leffers H, Tazi J, Helene C, Mergny JL (2000) Identification of two human nuclear proteins that recognise the cytosine-rich strand of human telomeres in vitro. Nucleic Acids Res 28: $1564-1575$

Lambotte L, Saliez A, Triest S, Tagliaferri EM, Barker AP, Baranski AG (1997) Control of rate and extent of the proliferative response after partial hepatectomy. Am J Physiol 273: G905-G1112

Leman ES, Getzenberg RH (2002) Nuclear matrix proteins as biomarkers in prostate cancer. J Cell Biochem 86: $213-223$

Mandal M, Vadlamudi R, Nguyen D, Wang RA, Costa L, Bagheri-Yarmand R, Mendelsohn J, Kumar R (2001) Growth factors regulate heterogeneous nuclear ribonucleoprotein $\mathrm{K}$ expression and function. J Biol Chem 276: 9699-9704

Michelotti EF, Michelotti GA, Aronsohn AI, Levens D (1996) Heterogenous nuclear ribonucleoprotein $\mathrm{K}$ is a transcription factor. Mol Cell Biol 16: $2350-2360$

Michelotti EF, Tomonaga T, Krutzsch H, Levens D (1995) Cellular nucleic acid binding protein regulates the CT element of the human c-myc protooncogene. J Biol Chem 270: 9494-9499

Neumann AA, Reddel RR (2002) Telomere maintenance and cancer-look, no telomerase. Nat Rev Cancer 2: 879-884

Ostareck-Lederer A, Ostareck DH, Neubauer G, Bomsztyk K, Superti-Furga G, Hentze MW (2002) c-Src mediated phosphorylation of hnRNP K drives translational activation of specifically silenced mRNAs. Mol Cell Biol 22: $4535-4543$

Ostareck DH, Ostareck-Lederer A, Wilm M, Thiele BJ, Mann M, Hentze MW (1997) mRNA silencing in erythroid differentiation: hnRNP K nad hnRNP E1 regulate 15-lipogenase translation from the $3^{\prime}$ end. Cell 89 $597-606$

Ostrowski J, Kawata Y, Schullery DS, Denisenko ON, Bomsztyk K (2003a) Transient recruitment of the hnRNP $\mathrm{K}$ protein to inducibly transcribed gene loci. Nucleic Acids Res 14: 3954-3962

Ostrowski J, Kawata Y, Schullery D, Denisenko ON, Higaki Y, Abrass CK Bomsztyk K (2001) Insulin alters heterogeneous ribonucleoprotein $\mathrm{K}$ protein binding to DNA and RNA. Proc Natl Acad Sci USA 98: 90449049

Ostrowski J, Schullery DS, Denisenko ON, Higaki Y, Watts J, Aebersold R, Stempka L, Gschwendt M, Bomsztyk K (2000a) Role of tyrosine phosphorylation in the regulation of the interaction of heterogenous nuclear ribonucleoprotein $\mathrm{K}$ protein with its protein and RNA partners. J Biol Chem 275: 3619-3628

Ostrowski J, Sims JE, Sibley CH, Valentine MA, Dower SK, Meier KE, Bomsztyk K (1991) A serine/threonine kinase activity is closely associated with a $65-\mathrm{kDa}$ phosphoprotein specifically recognized by the kappa B enhancer element. J Biol Chem 266: 12722 - 12733

Ostrowski J, Van Seuningen I, Seger R, Rouch CT, Sleath PR, McMullen BA, Bomsztyk K (1994) Purification, cloning, and expression of a murine phosphoprotein that binds the $\kappa \mathrm{B}$ motif in vitro identifies it as the homolog of the human hnRNP $\mathrm{K}$ protein. Description of a novel DNA-dependent phosphorylation process. J Biol Chem 269: $17626-17634$ 
Ostrowski J, Wocial T, Skurzak H, Bartnik W (2003b) Do altering in ornithine decarboxylase activity and gene expression contribute to antiproliferative properties of COX inhibitors? $\mathrm{Br} J$ Cancer 88: $1143-1151$

Ostrowski J, Woszczynski M, Kowalczyk P, Trzeciak L, Hennig E, Bomsztyk K. (2000b) Treatment of mice with EGF and orthovanadate activates cytoplasmic and nuclear MAPK, p70S6k, and p90rsk in the liver. J Hepatol 32: 965 - 974

Ostrowski J, Woszcznski M, Kowalczyk P, Wocial T, Henning E, Trzeciak L, Janik P, Bomsztyk K (2000c) Increased activity of MAP, p70S6 and p90rs kinases is associated with AP-1 activation in spontaneous liver tumours, but not in adjacent tissue in mice. $\mathrm{Br} J$ Cancer 82: $1041-1050$

Rozga J (2002) Hepatocyte proliferation in health and in liver failure. Med Sci Monit 8: RA32 - RA38

Samuel SK, Spencer VA, Bajno L, Sun JM, Holth LT, Oesterreich S, Davie JR (1998) In situ cross-linking by cisplatin of nuclear matrix-bound transcription factors to nuclear DNA of human breast cancer cells. Cancer Res 58: 3004-3008

Shnyreva M, Schullery DS, Suzuki H, Higaki Y, Bomsztyk K (2000) Interaction of two multifunctional proteins. Heterogeneous nuclear ribonucleoprotein $\mathrm{K}$ and Y-box binding protein. J Biol Chem 275: 15498 - 15503

Schullery DS, Ostrowski J, Denisenko ON, Stempka L, Shnyreva M, Suzuki H, Gschwendt M, Bomsztyk K (1999) Regulated interaction of protein kinase $\mathrm{C} \delta$ with the heterogeneous nuclear ribonucleoprotein $\mathrm{K}$ protein. J Biol Chem 274: 15101 - 15109
Siomi H, Matunis MJ, Michael WM, Dreyfuss G (1993) The pre-mRNA binding protein contains a novel evolutionary conserved motif. Nucleic Acids Res 21: $1193-1198$

Spiewak Rinaudo JA, Thorgeirsson SS (1997) Detection of a tyrosinephosphorylated form of cyclin A during liver regeneration. Cell Growth Differ 8: $301-309$

Szymanska H (1991) Morphological classification of spontaneous liver tumours in 4 inbred mouse strains. Zwierz Lab 28: 77-86

Taub R (1996) Transcriptional control of liver regeneration. FASEB J 10: $413-427$

Taub R, Roy A, Dieter R, Koontz J (1987) Insulin as a growth factor in rat hepatoma cells. Stimulation of protooncogene expression. J Biol Chem 262: $10893-10897$

Van Seuningen I, Ostrowski J, Bustelo X, Sleath P, Bomsztyk K (1995) The $\mathrm{K}$ protein domain that recruits the IL-1-responsive $\mathrm{K}$ protein kinase lies adjacent to a cluster of Src- and Vav-SH3-binding sites. Implications that K protein acts as a docking platform. J Biol Chem 270: 26976-26985

Wang JYJ (1994) Nuclear protein tyrosine kinases. TIBS 19: $373-376$

Weng Z, Thomas SM, Rickles RJ, Taylor JA, Brauer AW, Seidel-Dugan C, Michael WM, Dreyfuss G, Brugge JS (1994) Identification of Scr, Fyn, Lyn SH3-binding proteins: implications for a function of SH3 domains. Mol Cell Biol 14: 4509-4521

Wolf HK, Michalopoulos GK (1992) Hepatocyte regeneration in acute fulminant and nonfulminant hepatitis: a study of proliferating cell nuclear antigen expression. Hepatology 15: 707-713

Zimmermann A (2002) Liver regeneration: the emergence of new pathways. Med Sci Monit 8: RA53 - RA63 